\title{
INTERNATIONAL STANDARDS - AN IMPORTANT COMPONENT OF A SUCCESSFUL DIGITAL TRANSFORMATION OF THE NATIONAL ECONOMY
}

\author{
Marijana VIDAS-BUBANJA ${ }^{1}$, Srđan BOGETIĆ ${ }^{2}$, Iva BUBANJA ${ }^{2}$ \\ ${ }^{1}$ Belgrade Business Academy for Applied Studies, 11000 Belgrade, Kraljice Marije 73, Republic of Serbia, \\ E-mail: marijana.bubanja@bbs.edu.rs \\ ${ }^{2}$ Belgrade Business Academy for Applied Studies, 11000 Belgrade, Kraljice Marije 73, Republic of Serbia
}

Paper received: 23.03.2019.; Paper accepted: 08.05.2019.

\begin{abstract}
Digital transformation is a term that is, as of late, becoming an increasingly important topic of discussion, among both government authorities (in developed and developing countries) and entrepreneurs as well. Through the process of digital transformation, enterprises acquire the power to create new values for end-users, employees and the enterprises themselves more efficiently, and thus become more competitive and better positioned on the global market. In the overall process of digital transformation, an important role is played by the government, which needs to create an environment marked by the presence of supply (provided by enterprises) and demand from the end-users. The education of the companies' employees, as well as the users, is a decisive element that will decide whether digital transformation will work out in a particular market. The important role of the government is also shown in the adoption and implementation of international standards that provide businesses with a certain level of certainty when it comes to data protection and security in the digital sphere. The Republic of Serbia has asserted its determination to be more actively involved in the process of the digital transformation of the national economy, but unfortunately, the efforts aimed at this endeavour still fall short in comparison to the countries in the South East Europe region.
\end{abstract}

Keywords: Digital Transformation, Education, Standards, Security, Development.

\section{INTRODUCTION}

Ever since the late $1990 \mathrm{~s}$, the business environment has been changing profoundly, under the strong impact of intensive technological developments, changes in competitive relations and the effects of the 2008 global economic crisis. The world is entering a new level of economic globalization in which national economies have become tightly interconnected and are faced with a need to monitor and respond to the challenges and dynamics of the new business environment. At the micro-level of their activities, business organizations have to create novel business models corresponding to the observed and anticipated changes in the environment if they are to maintain their competitive ability in the long run and provide for constant growth dynamics (Đorđević et al., 2016).
Modern enterprises are bolstering their strategies and business operations models with an intensive implementation of information and communications technologies (ICT). Through the digital transformation of their entire work and business operations, companies try to adapt quickly to new market trends and to approach their demanding customers in novel ways. New digital business solutions offer companies a possibility to differentiate and personalize products to be tailored in accordance with customers' specific wants and needs (Vidas-Bubanja et al, 2017). Digital platforms represent a new business model that enables companies to find new opportunities for the trade of goods and services on a global level through the application of new digital technologies. 
Digital transformation constitutes a radical shift in the business philosophy of an enterprise and the breaking up with past business practices. Company management today is facing the challenge of embracing the new business philosophy that asks for quality change management and includes the following segments: empowering employees with digital skills, changing the company's way of communication with end-users, changes in the overall organizational culture.

Apart from the benefits, intensive development of new technologies has its downsides too, and they arise from the fact that companies have to take into account risk management, computer information security and data security. Certain events over the past few years have shown that some large companies have had considerable material costs as a result of inadequate data security considerations.

Therefore, the implementation of international standards, as well as integrated management systems, is considered a necessary tool today enabling a company further adjustment to new market changes. The International Organization for Standardization (ISO), in co-operation with the International Electrotechnical Commission (IEC), has upgraded the existing and developed a whole new set of standards covering the area of the $4^{\text {th }}$ Industrial Revolution. The development of the standardized Annex Sl form has facilitated the integration of international standards in a company and the achievement of business excellence.

Digital transformation in Serbia is still in the process of development, although it has been a topic of intensive discussions over the past several years. Local ICT companies are relatively slow in the implementation of digital technologies in their business processes, which is closely related to under-investment in research and development. By creating a stimulating environment, the government should promote successful exemplars of domestic ICT companies and in this way motivate and support young entrepreneurs and start-up companies in the field of ICT. However, besides motivation and financial resources to launch start-ups, what is also a prerequisite is knowledge, and not only in the field of ICT but also in the areas of management and entrepreneurship.

\section{THE IMPORTANCE OF DIGITAL TRANSFORMATION FOR CONTEMPORARY BUSINESS PRACTICES}

To be able to talk about the impact of digital transformation on economic dynamics and economic growth at a macro-level, what is of primary importance is the implementation of digital technologies at the micro-level of companies, as they are the ones that carry out and drive that economic dynamism with their more flexible and efficient ICT-based business operations. By the term digital enterprise, we refer to those companies that are characterized by highintensity utilisation of novel digital technologies (particularly social media, big data analytics, mobile technologies, and cloud solutions) with the aim of improving business operations, inventing new business models, enhancing business intelligence and engaging with customers and stakeholders. They contribute to the creation of new jobs and growth opportunities of the future (EC, 2015).

By going digital, companies will be able to face the novel requirements related to the product itself, to business processes, business models, required knowledge and skills and the global business environment, by acting in the following manner (RBSC, 2014):

- Customers - customer expectations are changing as they are becoming more demanding and more experienced, armed with numerous information on the offer and the products and services they can now access. The primary benefit of digital technologies is reflected in higher interactivity with customers and an enhanced capability of meeting their expectations, which is definitely going to remain the critical element of competitiveness in the forthcoming period.

- Products and services - the quality of products and services is improving. From the point of view of the present-day customer, a product should be personalized, locally produced through mass customisation. Production-wise, the process of digitalisation brings more freedom and flexibility into the production process itself, making it possible, with relatively low marginal costs, to make a product tailored to the needs of the individual user.

- Partnerships - new partnerships are being created between companies because mutual 
collaboration has become key to maintaining a competitive edge on the market. The business operations of modern digital enterprises should support the networked manufacturing concept and cluster dynamics. A shift may be seen in the distribution of power between multinationals and small and medium-sized enterprises (SMEs), or very focused market players.

- The business models being implemented are based on the re-shuffling of the value chains and the blurring of the frontiers between products and services. Smart connected products now come with services, so customers are adopting new behaviour habits in terms of "ownership", co-creation and sharing (the app market) (DG CONNECT/A, \& EC, 2016).

\section{THE CHALLENGES OF DIGITAL TRANSFORMATION IN SERBIA}

The Republic of Serbia has recognized the fact that the transition to information society and digital economy through the widespread use of information and communications technologies and smart industries is crucial for further economic growth. Institutional support for a more dynamic digitalisation process relies on the Strategy for the Development of the Information Society by the year 2020, in which top priorities have been identified in six key areas: further development of electronic communications, e-government, ehealth, e-justice, ICT in education, science and culture, and a streamlined development of ebusiness and the ICT business sector. This strategy is part of the Digital Agenda for Serbia, according to which the development of a digital society should be geared towards maximizing the potential of ICT aimed at increasing efficiency, economic growth, employment and improving the quality of life (Serbian Government, 2010).

In the past decade, Serbia has made significant progress in the area of the development of the infrastructure required for the implementation and application of digital technologies; yet certain divides are still present, be it in comparison to the developed countries, Europe, the countries in the region, or in terms of the differences among individual industrial branches, companies, or regions within the national economy itself. Fundamental indicators of the evolving digital economy in Serbia are the extent to which enterprises and people have affordable access to relevant ICTs and digital solutions, and whether they make productive use of them. While ICT uptake is improving, the wide variations in the extent to which businesses and individuals are making effective use of ICTs need to be addressed (UNCTAD, 2017).

Access to digital technologies in the Republic of Serbia keeps growing steadily, be it in terms of individuals, households or companies. In 2018, all companies in Serbia had Internet access, and in addition, over $70 \%$ of individuals and households had access to this global network (Table 1) (SORS, 2018).

Table 1. Accessibility of ICT in Serbia

\begin{tabular}{|l|c|c|c|}
\hline & $\mathbf{2 0 1 0}$ & $\mathbf{2 0 1 5}$ & $\mathbf{2 0 1 8}$ \\
\hline INDIVIDUALS & & & \\
\hline $\begin{array}{l}\text { \% of individuals using } \\
\text { the Internet }\end{array}$ & 40,9 & 65,3 & 73,4 \\
\hline HOUSEHOLDS & & & \\
\hline $\begin{array}{l}\text { \% of households with } \\
\text { Internet access from home }\end{array}$ & 39,0 & 63,8 & 72,9 \\
\hline ENTERPRISES & & & \\
\hline $\begin{array}{l}\text { \% of enterprises with } \\
\text { Internet access }\end{array}$ & 96,8 & 99,1 & 99,8 \\
\hline
\end{tabular}

Source: SORS, 2018

Although important, access is only one ingredient in the recipe for success in the Serbian digital transformation process. If we look at the indicators of the utilisation of network connections in performing business activities (e-commerce transactions) or engaging in social services (use of e-government services), Serbia's lagging behind becomes more evident. In 2018, 41.9\% of companies bought products/services online, and only $23.3 \%$ of companies received orders (excluding e-mail orders) placed over the Internet (SORS, 2018).

Domestic enterprises are beginning to take advantage of the benefits of the WEB 2.0 service, and $37.9 \%$ of the companies use some of the social networks for their business purposes. Domestic companies fall behind when it comes to supply chain management as the percentage of companies using ERP and CRM software is still low $(18 \%$ and $24 \%$, respectively). In 2008 , only $15.5 \%$ of enterprises pay for Internet cloud computing services. As far as individual Internet users in Serbia are concerned, they are noticeably present on social networks $(70.3 \%)$, but are significantly less active buying over the Internet $(30.9 \%)$ or using Internet banking services (20.4\%) (Table 2). 
M. Vidas-Bubanja International standards - an important component of a successful

et al. digital transformation of the national economy

If we are to observe the process of digital transformation in the Republic of Serbia, given its strategic orientation aimed at acquiring full membership status in this regional integration, perhaps the most relevant comparison would be to the EU and its member states, The digitalisation of the member state economies is tracked through the European Commission's DESI Index - Digital Economy and Society Index. This index compares individual EU countries over 5 components of digitalisation: connectivity, human capital, use of the Internet, the integration of digital technology in business and e-commerce, digital public services. According to this index, the most advanced digital economies in the European Union are Denmark, Finland, Sweden, whereas Bulgaria, Greece, and Romania are to be found at the bottom of the list.

Table 2. ICT usage in the Republic of Serbia

\begin{tabular}{|c|c|c|}
\hline & 2015. & 2018. \\
\hline \multicolumn{3}{|l|}{ INDIVIDUALS } \\
\hline$\%$ of individuals using the Internet for interaction with public authorities & 27.8 & 37.3 \\
\hline$\%$ of individuals using the Internet for buying goods and services & 22.7 & 30.9 \\
\hline$\%$ of individuals using the Internet for participating in social networks & 75.6 & 70.3 \\
\hline$\%$ of individuals using Internet banking & 12.9 & 20.4 \\
\hline \multicolumn{3}{|l|}{ ENTERPRISES } \\
\hline$\%$ of enterprises with a Website & 72.5 & 82.6 \\
\hline$\%$ of enterprises receiving orders placed online & 23.3 & 26.3 \\
\hline$\%$ of enterprises buying products/services via the Internet & 41.0 & 41.9 \\
\hline$\%$ of enterprises using social networks & 28.6 & 39.7 \\
\hline$\%$ of enterprises using ERP & 14.9 & $18(2017)$ \\
\hline$\%$ of companies using CRM & 14.9 & $24(2017)$ \\
\hline$\%$ of companies using cloud services & 9.2 & 15.5 \\
\hline
\end{tabular}

Source: SORS, 2015; SORS, 2018

For Serbia, DESI has been calculated since 2017. On the 2017 DESI score, Serbia is ranked $27^{\text {th }}$, which places it in the cluster of countries with relatively low performances, encompassing: Romania, Greece, Bulgaria, Italy, Poland, Hungary, Croatia, Cyprus, and the Slovak Republic. In terms of the index value, Serbia is also below the average of the EU countries in the region (RATEL, 2017). Table 3 shows the positions of the European countries in the field of the digital economy. With its index rating of $35.6 \%$, Serbia is, unfortunately, worse placed not only in comparison to the developed countries of the EU but also to the countries in the region. Therefore, it is necessary to work on improving all the segments having an impact on the development of the digital economy.

Table 3. Comparative DESI overview

\begin{tabular}{|l|c|}
\hline & \% \\
\hline EU average & 50.8 \\
\hline $\begin{array}{l}\text { The cluster of comparable } \\
\text { countries* }\end{array}$ & 40.4 \\
\hline EU countries in the region** & 40,8 \\
\hline
\end{tabular}

* Cluster of comparable countries includes countries at a similar level of digital development: Romania, Greece, Bulgaria, Italy, Poland, Hungary, Cyprus, and Slovakia.

**EU countries in the region: Slovenia, Hungary, Romania, Bulgaria, Croatia, and Greece. Source: RATEL, 2017
One of the more important segments in this regard is certainly the one linked to knowledge and the quality of human capital. Namely, the IDI Skills Sub-Index identifies the digital skills needed to take an active part in a digital society as well as to use digital products and services. Digital skills and Internet access are the infrastructures of a digital economy and society. Among the EU Member States, Finland, Luxembourg and the Netherlands fall into countries where digital skills are highly developed, whereas Greece, Bulgaria, and Romania are countries where this area is still at a low level. According to the RATEL data (RATEL, 2017), Serbia is ranked $19^{\text {th }}(48.6 \%)$, which is below the European average, but above the value calculated for the cluster of comparable countries $(40.6 \%)$ and above the regional average (41\%).

Table 4 explains in more detail the segment related to human capital in Serbia upon which we can arrive at the following two conclusions. Firstly, there is a high percentage of Internet users with basic digital skills, and secondly, presenting the biggest problem at the same time, there is a low percentage of ICT specialists, that is, highly-skilled staff. By raising the enrolment quotas at faculties and colleges, the Government is trying to come up 
with a sufficient number of ICT specialists, but unfortunately, it is still not enough. According to the VOICT data, Serbian companies employ three times fewer ICT experts than the world average (Matijević \& Šolaja, 2018).

Table 4. Human Capital - indicators

\begin{tabular}{|l|c|}
\hline $\begin{array}{l}\text { 2a2 Internet users with at least } \\
\text { basic digital skills }\end{array}$ & $64.9 \%$ \\
\hline 2b1 ICT specialists & $2.1 \%$ \\
\hline $\begin{array}{l}\text { 2b2 STEM (Science, Technology, } \\
\text { Engineering and Maths) graduates }\end{array}$ & 17.1 \\
\hline
\end{tabular}
Source: RATEL, 2017.

In comparison to the European Union (EU) countries, the domestic ICT sector is insufficiently developed, which significantly hampers a faster digital transformation process in the national economy. The structure of the domestic ICT sector is dominated by hardware production $(44.8 \%)$, followed by IT services (37.1\%), whereas the production of software, which can generate the highest profit rates, is only in the third place (18.1 $\%$ ) (Table 5). Domestic ICT companies invest only $0.7 \%$ of their revenues in further business improvements, which is significantly lower than the world average (Matijević \& Šolaja, 2018). The Government of the Republic of Serbia has shown an understanding of the problem faced by domestic ICT companies and has decided to help this industry by adopting the Amendments to the Law on Income Tax. Furthermore, this year's plan is to adopt a law that would facilitate the operation of venture funds.

Table 5. Serbian IT market structure vs. Profit in the IT sector

\begin{tabular}{|l|c|c|}
\hline & $\begin{array}{c}\text { Structure } \\
(\mathbf{\%})\end{array}$ & $\begin{array}{c}\text { Profit } \\
\text { rate (\%) }\end{array}$ \\
\hline IT Hardware & 44.8 & 14.5 \\
\hline Software & 18.1 & 59.5 \\
\hline IT Services & 37.1 & 26 \\
\hline
\end{tabular}

Source: Matijević \& Šolaja, 2018, p. 37

The findings from a research study conducted in 2015 show that domestic ICT companies consider the following as their three highest comparative advantages: quality service $(100 \%)$, technical know-how $(88.2 \%)$ and prices $(82.3 \%)(\mathrm{E} 3,2015)$. The question of price, that is lower labour costs, is the reason underlying an increase in the number of newly established companies and individuals working for foreign companies today.

The issue of digital transformation is also of great importance for the domestic small and medium- sized enterprises (SMEs) sector, as it encompasses the majority of enterprises and employs the highest number of workers. Digital technologies provide small and medium-sized enterprises with broad access to the global market and increase their chances of cooperation with large companies and systems. Domestic SMEs from the ICT sector have realized that joining into clusters will give them greater chances for achieving competitiveness in the domestic and foreign markets. There are currently three ICT clusters in Serbia: ICT Cluster of Central Serbia, Vojvodina ICT Cluster and the Nis Cluster of Advanced Technologies (NiCAT). The Government, for its part, seeks to support the development and digitalisation of small and medium-sized enterprises. In this regard, when it comes to supporting the development of entrepreneurship in Serbia, it should be emphasized that it is being carried out at two levels: state and private. In practice, there are several state-owned entrepreneurship initiatives such as the Development Agency of Serbia (RAS), Innovation Fund, Science and Technology Park (STP) and others. Private programmes aimed at entrepreneurship development in the ICT sector include Startit, ICT HUB, Impact Hub Belgrade, Novi Sad Business Incubator, Kragujevac ecosystem, etc.

\section{INTERNATIONAL STANDARDS AS A SIGNIFICANT FACTOR IN DIGITAL TRANSFORMATION}

Accenture analysis shows a clear correlation between the health of an economy's environment enablers and the levels of digital investment and activity. An environment conducive to the development and success of the digital business models is based on the following (Morvan et al., 2016):

1) Digital user size and savviness, as well as readiness to use the network - countries with a large installed digital base and uniform culture, language and regulations have a competitive edge;

2) The existence of digital talents and educated entrepreneurs - science, technology, engineering and mathematics (STEM), entrepreneurial and creative skills is fundamental in enabling digital innovation;

3) Technological readiness in terms of infrastructure development and investment levels in the next generation networks will 
M. Vidas-Bubanja International standards - an important component of a successful

et al. digital transformation of the national economy

influence platform generation, growth and scale;

4) Existence of an open innovation system and innovation culture - the government needs to foster innovation hubs, bringing together universities, laboratories, start-ups, and large businesses;

5) Adaptive policies and regulations for new business models - demands proactive and participative policymaking, working jointly with platform players and other stakeholders on complex areas, such as data privacy, standardization, blockchain or cybersecurity.

The process of implementing digital technologies in business goes hand in hand with the standardization process. ICT standardisation forms the backbone of the digital transformation of industry, including the manufacturing industry, the agricultural sector, and future consumer products. The aim of ICT standards is to enable that connected devices can seamlessly and reliably work together - both in the industrial context and for consumer goods. This should be regardless of manufacturer, operating system or other technical details, and include the possibilities for data interoperability and portability between platforms (EC, 2016).

Developing standards for the digital world have to be based on open, voluntary standards, grounded in bottom-up and market-led approaches. Only such standards can be an important tool in the context of fast-developing technologies. ICT standards and related guidelines are also very important in order to maintain current levels of safety, ensure trust based on enhanced levels of digital security and privacy, improve energy and resource efficiency, and address emerging social and organizational challenges brought about by the digital transformation.

The development of standards and standards-based interoperability are critical for the development of Industry 4.0 and the IoT, including smart cities and smart mobility. The key to success lies in inclusive standards development, built on collaboration and co-operation among the many players that make up the standards ecosystem. Advanced governance frameworks - building upon both existing publicand private-sector-led processes and new multistakeholder initiatives for the benefit of all - are necessary to effectively address the complexity of today's ICT standardization process (OECD, 2017).
Different organizations deal with the ICT standardization process both at national or regional level, such as the European Committee for Standardization-European Committee for Electrotechnical Standardization (CENCENELEC), European Telecommunications Standards Institute (ETSI), Telecommunications Industry Association (TIA), International Committee for Information Technology Standards (INCITS), etc., as well as the globally acting International Electrotechnical Commission (IEC), International Organization for Standardization (ISO) and International Telecommunication Union (ITU). There are other globally active organizations but with direct membership models, such as IEEE (a technical professional organization that among other things, develops standards), Internet Engineering Task Force (IETF), Organization for the Advancement of Structured Information Standards (OASIS), and World Wide Web Consortium (W3C).

Some authors believe that there can be no smart industry without standardization. In October 2018, the International Organization for Standardization promoted ISO standards and their role in society and the economy through social networking platforms. The reason for opting for this type of promotional campaign lies in the fact that this organization wants to timely prepare its members for the 4th Industrial Revolution.

In this context, it is interesting to highlight the activities of the ISO and IEC sister organizations that have worked on the revision of the existing, as well as on the creation of new standards, such as ISO 17789:2014 (Information Technology - Cloud Computing - Reference Architecture), ISO 27000:2018 (Information Technology - Security Techniques - Information Security Management Systems - Overview and Vocabulary), ISO 27001 Information Security Management System (ISMS), ISO 30141:2018 - the Internet of Things (IoT) Reference Architecture). These activities have two objectives: to clearly define new concepts in the field of IT (e.g. the Internet of Things) in order to apply them in business practice more efficiently and to unify international standards according to the Annex S1, leading to a facilitated integration of enterprise management systems in companies.

For example, the ISO 27000 series of standards will help a company to assess its purely technological needs, whereas the ISO 31000 series 
M. Vidas-Bubanja International standards - an important component of a successful

et al. digital transformation of the national economy

of standards will help the company understand the value of the information or products it holds in cyberspace, and therefore the importance of the degree of technological protection needed to prevent any kind of attack (Bartram, 2019). The application of ISO 27000 standards provides organizations with the security of information that can be related to information in the areas of finance, intellectual property, employee data, as well as with the ability to manage the risks that hamper enterprises in the digital economy.

When it comes to data security, we need to mention the General Data Protection Regulation (GDPR), prescribed by the European Union as of May 25th last year. This new legal framework defines how EU citizen data may be used. It follows that any organization that processes data of EU subjects in any way will have to comply with the new rules on personal data protection, even if its headquarters are outside the territory of the EU (Krivokapić \& Krivokapić, 2017). Google was the first company to pay a penalty for the breach of GDPR. A fine of 50 million Euros was paid in France.

Tables 6 and 7 show the number of certificates issued by ISO 27001 by different countries. According to Table 6, the largest number of companies certified according to this standard

come from Europe (5), followed by Asia (4) and the USA. Table 7, however, indicates that the Asia region is experiencing higher growth rates in the application of all three international standards (ISO 20000-1, ISO 27001, ISO 9001) compared to Europe in the 2016-2017 period. This may be attributed to the fact that the region of Asia has intensified the adoption of ICT in business (certain countries in particular), and that the majority of companies in this region realize the importance of applying the ISO 20000-1, ISO 27001, ISO 9001 standards.

Table 6. The top ten countries by the number of ISO 27001 certificates in 2016

\begin{tabular}{|c|l|c|}
\hline No. & \multicolumn{1}{|c|}{ Country } & $\begin{array}{c}\text { Number of } \\
\text { certificates }\end{array}$ \\
\hline 1 & Japan & 8.945 \\
\hline 2 & United Kingdom & 3.367 \\
\hline 3 & India & 2.902 \\
\hline 4 & China & 2.618 \\
\hline 5 & Germany & 1.338 \\
\hline 6 & Italy & 1.220 \\
\hline 7 & USA & 1.115 \\
\hline 8 & Taipei, China & 1.087 \\
\hline 9 & Spain & 752 \\
\hline 10 & the Netherlands & 670 \\
\hline \multicolumn{2}{|c|}{ Source: ISO, 2018a } \\
\hline
\end{tabular}

Table 7. Percentage of enterprises certified according to ISO 20000-1, ISO 27001, ISO 9001 standards in Europe, East Asia and the Pacific

\begin{tabular}{|l|c|c|c|c|c|c|}
\hline \multirow{2}{*}{ Region } & \multicolumn{2}{|c|}{ ISO 20000-1 } & \multicolumn{2}{c|}{ ISO 27001 } & \multicolumn{2}{c|}{ ISO 9001 } \\
\cline { 2 - 7 } & $\mathbf{2 0 1 6}$ & $\mathbf{2 0 1 7}$ & $\mathbf{2 0 1 6}$ & $\mathbf{2 0 1 7}$ & $\mathbf{2 0 1 6}$ & $\mathbf{2 0 1 7}$ \\
\hline Europe & $29.1 \%$ & $29.5 \%$ & $37.6 \%$ & $37.0 \%$ & $40.8 \%$ & $36.7 \%$ \\
\hline East Asia and the Pacific & $49.1 \%$ & $48.9 \%$ & $44.2 \%$ & $44.5 \%$ & $43.4 \%$ & $48.6 \%$ \\
\hline
\end{tabular}

The project "Regional market report on recognized IT quality standards", which was carried out in 2014, covering part of the Western Balkans market (Northern Macedonia, the Republic of Serbia, Bosnia and Herzegovina, Albania, Kosovo) has revealed that companies in these markets are showing an interest in applying IT quality standards. According to its market presence, the international standard ISO 9001 is the most dominant one, which may be due to the fact that governments have bound companies with the application of this standard to fulfill legal obligations for participation in public procurement processes. In addition to the international ISO 9001 standard, companies are also interested in ISO 27001 and ISO 20000-1. However, it should be borne in mind that many of the companies in this region do not apply any of the standards.

As far as Serbia is concerned, research results show that $25 \%$ of the respondents do not apply IT quality standards. At the same time, almost half of the companies participating in the survey recognize the IT quality standards as an added value to their services and products, but also as a differentiating factor. In addition, about $40 \%$ of the respondents identified these standards as a minimum requirement for entry into the market and a competitive presence (Trajkovski \& Partners, 2014). When it comes to company plans for the future, Serbian companies emphasize the implementation of international standards (ISO 
27001, ISO 20000-1) as a top priority and, to a lesser extent, the application of the Six Sigma tool, as well.

An analysis of the representation of the ISO 20000-1, ISO 27001 and ISO 9001 series of standards certificates in the Western Balkans and countries in the region shown in Table 8 indicates that, compared to others, three countries (Romania, Hungary and Bulgaria) are standing out in terms of the intensity of their engagement in the process of the certification of their companies. Of the countries of former Yugoslavia, the Republic of Serbia has the largest number of certified companies in all the three analysed series of standards. However, from the aspect of the national economy, this number of certified companies is still insufficient and much more needs to be done to promote this standard as well as all the other international standards.

Activities aimed at promoting the implementation of the standards are also extremely important, and an interesting example might be that of the Netherlands, which through its NEN organization (a representative of this country in ISO), has, in order to bring the standards closer to the digital economy, created the Smart Industry Standardization Platform, the main purpose of which is to (van Terwisga, 2018):

- coordinate standardization activities in the smart industry;

- identify standardization needs in smart industry laboratories;

- disseminate information on smart industry standardization.

Table 8. Number of ISO 20000-1, ISO 27001i and ISO 9001series of standards certificates in the countries of the Western Balkans and the region

\begin{tabular}{|l|c|c|c|c|c|c|}
\hline \multirow{2}{*}{\multicolumn{1}{c|}{ Countries }} & \multicolumn{2}{|c|}{ ISO 2000-1 } & \multicolumn{2}{c|}{ ISO 27001 } & \multicolumn{2}{c|}{ ISO 9001 } \\
\cline { 2 - 7 } & $\mathbf{2 0 1 6}$ & $\mathbf{2 0 1 7}$ & $\mathbf{2 0 1 6}$ & $\mathbf{2 0 1 7}$ & $\mathbf{2 0 1 6}$ & $\mathbf{2 0 1 7}$ \\
\hline Slovenia & - & - & 50 & 57 & 1.848 & 1.720 \\
\hline Croatia & 8 & 10 & 55 & 110 & 2.659 & 2.381 \\
\hline Macedonia & 16 & 16 & 13 & 17 & 286 & 444 \\
\hline Serbia & 9 & 15 & 142 & 146 & 3.017 & 2.213 \\
\hline Montenegro & - & - & 1 & 0 & 92 & 46 \\
\hline Bosnia \& Herzegovina & - & - & 13 & 17 & 1.037 & 1.140 \\
\hline Romania & 44 & 104 & 1.078 & 513 & 12.209 & 12.031 \\
\hline Bulgaria & 59 & 68 & 273 & 261 & 5.951 & 5.397 \\
\hline Hungary & 24 & 17 & 323 & 421 & 6.559 & 5.946 \\
\hline
\end{tabular}

\section{CONCLUSION}

In order to boost the competitiveness of the Serbian economy, the national development strategy must embrace and support faster development of the digital economy as a cornerstone for today's growth and positioning in a new market environment. Serbia is still at the very doorstep of embarking on the process of the digitalisation of economy and society because the speed at which we adopted and used new technologies was not fast enough. The rest of the developed world has moved forward further and faster than the Republic of Serbia in ICT-supported activities; it has opened platforms, found new solutions, experiences, and furthermore, it has also created a direct, new digital business structure that has contributed to faster growth of the gross domestic product.
Such a novel development orientation asks for a change in the country's economic system in such a way as to enable it to support new business models based on knowledge-intensive technologies. A necessary prerequisite for such an economic transformation of Serbia is that the national economy develops its infrastructural potentials and that each company adopts new ICT-based organizational and business models and develops a skilled workforce (Vidas-Bubanja et al., 2016).

The digital transformation of the national economy is inevitable, and the following activities are necessary for its successful implementation:

- Increasing investment in research and development in domestic ICT companies;

- Promoting digital business practices in the local market with the aim of developing awareness among the existing and prospective entrepreneurs; 
M. Vidas-Bubanja International standards - an important component of a successful

et al.

digital transformation of the national economy

- Raising the awareness of citizens as potential users on the advantages of using digital technologies;

- A more efficient collaboration among universities, academies of professional studies, the Serbian Chamber of Commerce, the Digital Serbia Initiative and other professional associations in the field of specialist education and training of young people in the use of digital tools;

- Reducing the regional divide in Serbia in the area of the implementation and use of ICT.

The development of the domestic IT sector could be a critical factor in the growth of the national digital economy and the digital transformation of domestic enterprises. Also, achieving maximum results from the application of digital technologies depends on the regulatory environment (not only ICT-related areas but also labour and product markets), costs and ease of launching a business, access to finance, as well as the implementation of international standards in the business.

The ISO 20000-1, ISO 27001 and ISO 9001 series of standards can help domestic companies develop a risk management strategy to effectively identify and mitigate risks in the cyber environment, thereby enhancing the likelihood of achieving their objectives and increasing the protection of their data and assets (ISO, 2018b). Domestic companies are aware of the importance of applying modern standards in business but are still not putting enough effort in their implementation, which directly slows down the very process of a successful digital transformation of the national economy.

\section{REFERENCES}

Bartram, R. (2019). The quest for cyber - trust. ISO Focus, January-February 2019., 24-31.

DG CONNECT/A, \& EC (2016). Digitising European Industry: reaping the full benefits of a Digital Single Market. Retrieved 10.03.2019, from European Commission

https://ec.europa.eu/futurium/en/system/files/ged/ne xt_steps_0.pdf

Đorđević D., Ćoćkalo D., \& Bogetić S. (2016). The analysis of marketing concept implementation in domestic enterprises. Journal of Engineering Management and Competitiveness (JEMC), 6(2), 120-128.

E3. (2015). South-East Europe IT Industry Barometer (SEE ITIB) 2015 Project: South-East Europe IT
Industry Barometer (SEE ITIB) 2015. Podgorica, Montenegro: E3 Consulting Ltd.

EC. (2015). ENTR/E4 - Fuelling Digital

Entrepreneurship in Europe - Background paper. Retrieved 15.03.2019, from European Commission http://ec.europa.eu/DocsRoom/documents/5313/atta chments/1/translations

EC. (2016). ICT Standardisation Priorities for the Digital Single Market (Communication From the Commission to the European Parliament, the Council, the European Economic and Social Committee and the Committee of the Regions ed.). Brussels: European Commission.

ISO. (2018a). The ISO Survey 2017 (The ISO Survey ed.): ISO.

ISO. (2018b). ISO 31000 - Risk management: ISO.

Krivokapić, D., \& Krivokapić, Đ. (2017). GDPR dolazi u Srbiju - sve što treba da znate o novoj regulativi za zaštitu podataka o ličnosti Retrieved 20.02.2019, from STARTIT https://startit.rs/gdpr-dolazi-usrbiju-sve-sto-treba-da-znate-o-novoj-regulativi-zazastitu-podataka-o-licnosti/

Matijević, M., \& Šolaja, M. (2018). ICT in Serbia - At a Glance. Novi Sad: Vojvodina ICT Cluster.

Morvan, L., Hintermann, F., \& Vazirani, M. (2016). Five Ways to Win with Digital Platforms. Retrieved 13.02.2019, from Accenture and G20 Young Entreprenuers' Alliance https://www.accenture.com/us-en/ acnmedia/PDF29/Accenture-Five-Ways-To-Win-With-DigitalPlatforms-Full-Report.PDF

OECD. (2017). Key Issues for Digital Transformation in the G20 (Report prepared for a joint G20 German Presidency/ OECD conference ed.). Berlin, Germany: OECD.

RATEL. (2017). An Overview of Telecom Market in the Republic of Serbia in 2017. Retrieved 01.03.2019., from Republic Telecommunication Agency (RATEL)

RBSC. (2014). INDUSTRY 4.0 The new industrial revolution - How Europe will succeed? Retrieved 20.02.2018., from Roland Berger Strategy Consultants Gmbh http://www.iberglobal.com/files/Roland_Berger_Ind ustry.pdf

Serbian Government (2010). Strategija razvoja informacionog društva u Republici Srbiji do 2020. Službeni Glasnik RS, 51/2010: Serbian Government.

SORS (2015). Usage of information and communication technologies in the Republic of Serbia, 2015.

Retrieved 20.03.2019., from Statistical Office of the Republic of Serbia http://www.stat.gov.rs/enus/oblasti/upotreba-ikt/

SORS (2018). Usage of information and communication technologies in the Republic of Serbia, 2018. Retrieved 20.03.2019., from Statistical Office of the Republic of Serbia http://www.stat.gov.rs/enus/oblasti/upotreba-ikt/

Trajkovski \& Partners (2014). D2: Regional market report on recognized IT quality standards Project: 
Identification of IT quality standards and certifications (required on regional markets). Skopje: SEGURA Consulting LLC.

UNCTAD. (2017). Information Economy Report 2017: Digitalization, Trade and Development. Retrieved 20.12.20189., from United Nations https://unctad.org/en/PublicationsLibrary/ier2017 en .pdf

van Terwisga, R. (2018). The road to industrial smartness. ISO Focus, November-December 2018., 34-39.
Vidas-Bubanja, M., \& Bubanja, I. (2016). The high quality and sustainability as characteristics of doing business in digital connected world. International Journal of Advanced Quality, 44(2), 7-12.

Vidas-Bubanja, M., \& Bubanja, I. (2017). The Challenge of going digital. Journal of Engineering Management and Competitiveness (JEMC), 7(2), 126-136.

\title{
MEĐUNARODNI STANDARDI - VAŽNA KOMPONENTA DIGITALNE TRANSFORMACIJE NACIONALNE EKONOMIJE
}

\begin{abstract}
Digitalna transformacija je termin koji je odnedavno postao sve važnija tema za diskusiju, kako među vladinim zvaničnicima (u razvijenim i zemljama u razvoju) tako i među preduzetnicima . Kroz proces digitalne transformacije, preduzeća stiču moć da efikasnije kreiraju nove vrednosti za krajnje korisnike, zaposlene i samo preduzeće, te tako postaju konkurentnija i bolje pozicionirana na globalnom tržištu. U ukupnom procesu digitalne transformacije, važnu ulogu ima vlada , koja treba da stvori okruženje obeleženo prisustvom snabdevanja (koje pružaju preduzeća ) i potražnjom od krajnjih korisnika . Obrazovanje zaposlenih u preduzećima , kao i korisnika , je odlučujući element koji će odlučiti da li će digitalna transformacija funkcionisati na određenom tržištu. Važna uloga vlade se takođe pokazuje u usvajanju i primeni međunarodnih standarda koji preduzećima pružaju izvestan nivo sigurnosti kada je reč o zaštiti podataka i bezbednosti u digitalnoj sferi. Republika Srbija je potvrdila svoju odlučnost da bude aktivnije uključena u proces digitalne transformacije nacionalne ekonomije, ali nažalost, napori usmereni na ovaj poduhvat još uvek se ne mogu porediti sa zemljama u regionu Jugoistočne Evrope.
\end{abstract}

Ključne reči: Digitalna transformacija, Obrazovanje, Standardi, Bezbednost, Razvoj. 